\title{
Florida's Native Bromeliads ${ }^{1}$
}

\author{
Barbra C. Larson, J. Howard Frank, Ginger M. Allen and Martin B. Main²
}

Bromeliads are members of the pineapple family Bromeliaceae. They are perennial herbs that lack woody stems and typically grow on other plants or substrates. Bromeliads are not mosses as some of their common names suggest. They are flowering plants, although their blossoms can be very small.

All of Florida's 16 native bromeliad species and two natural hybrids (hybrids are produced when cross-pollination occurs between species, producing a new offspring) are epiphytic, which means they grow on other plants. Although epiphytes may attach root structures to their host plant, they do not parasitize the host plant; they simply use it for support.

Often called "air plants," bromeliads absorb surface minerals and water from specialized disc-shaped leaf structures called trichomes. Most Florida bromeliads are "tank" bromeliads that hold water. Tanks are formed by many separate leaf axils (the space between the leaf and stem) or the central leaves together may form a large tank. Trapped plant materials (leaves, seeds, and twigs) are decomposed by bacteria and fungi and absorbed by the trichomes lining the bromeliad tanks. Sometimes found among these plant materials are dead and drowning non-aquatic insects, which also provide nutrients for the bromeliads. Catopsis berteroniana, a species of tank bromeliad found in south Florida, has evolved the ability to trap insects and utilize their nutrients to such a degree that it is essentially a carnivorous plant. Bromeliad tanks also provide habitat for mosquito larvae and various other invertebrate and small vertebrate animals. Consequently, bromeliads play important ecological roles, both as habitat and in nutrient recycling.

Ten of Florida's 16 native bromeliad species are listed as threatened or endangered. A threatened species is at risk of becoming endangered, and an endangered species is at risk of becoming extinct. Loss of habitat, illegal collecting of specimens from natural areas, and the non-native Mexican bromeliad weevil (Metamasius callizona) are the greatest threats to Floridas bromeliads. There is also a bromeliad weevil that is native to Florida (Metamasius mosieri), but whereas the native weevil does not typically kill the plant, the Mexican bromeliad weevils larvae typically do. The rapid spread of the Mexican bromeliad weevil throughout south Florida is a potentially serious threat to these rare plants. For more information on the Mexican bromeliad weevil problem, please see the additional information section

1. This document is Circular 1466, one of a series of the Department of Wildlife Ecology \& Conservation, Florida Cooperative Extension Service, Institute of Food and Agricultural Sciences (IFAS), University of Florida. Publication date: September 2004. Please visit the Edis Web site at http://edis.ifas.ufl.edu.

2. Barbra C. Larson, State Program Coordinator, Florida Yards \& Neighborhoods, and J. Howard Frank, Professor, Entomology and Nematology Department, IFAS, University of Florida, Gainesville, FL 32611; Martin B. Main, Associate Professor and Wildlife Extension Specialist, and Ginger M. Allen, Senior Biological Scientist, Southwest Florida Research and Education Center, IFAS, University of Florida, Gainesville, FL 32611.

The Institute of Food and Agricultural Sciences (IFAS) is an Equal Opportunity Institution authorized to provide research, educational information and other services only to individuals and institutions that function with non-discrimination with respect to race, creed, color, religion, age, disability, sex, sexual orientation, marital status, national origin, political opinions or affiliations. U.S. Department of Agriculture, Cooperative Extension Service, University of Florida, IFAS, Florida A. \& M. University Cooperative Extension Program, and Boards of County Commissioners Cooperating. Larry Arrington, Dean 
of this document and visit the "Save Floridas Native

Bromeliads" website

(http://savebromeliads.ifas.ufl.edu/).

This document describes the distinct features of each of Florida's 16 native bromeliads and notes specific conservation concerns. There are also two natural hybrids present in Florida, Tillandsia bartramii $\mathrm{x}$ fasciculata and Tillandsia balbisiana $\mathrm{x}$ fasciculata, which are not described in this document. We have used the symbol " " to represent the word approximately when discussing length of leaves, bracts, flowers, and seed capsules.

\section{Powdery strap airplant}

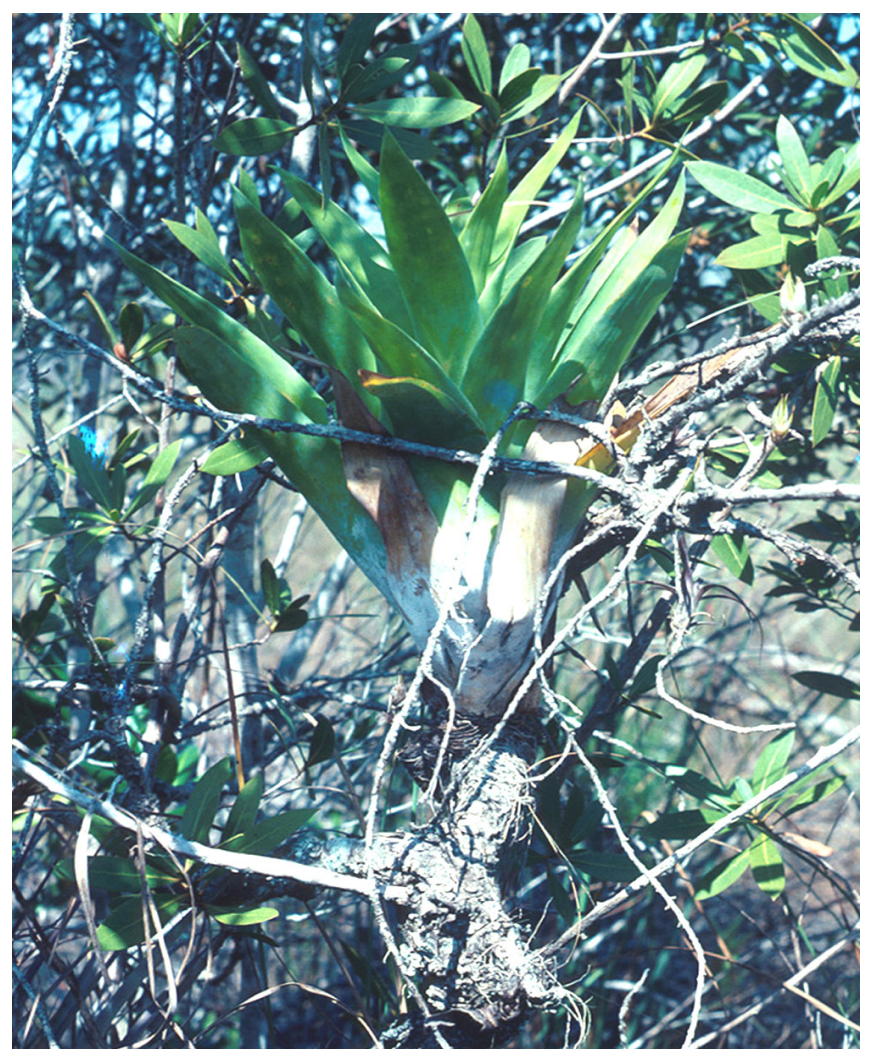

Powdery strap airplant. Credits: J. H. Frank

\section{Scientific name: Catopsis berteroniana}

Also called: Powdery catopsis, West Indies catopsis, Yellow catopsis, Mealy wild pine

$\underline{\text { Status in Florida: endangered; rare }}$

Threats in Florida: illegal collecting, Mexican bromeliad weevil, habitat loss
Range: Florida, Mexico, West Indies, Central/South America

Distribution in Florida: Collier, Dade, and mainland Monroe counties

Habitat: rockland hammock; slough; tidal swamp; prefers strong light, on high branches of host tree

Description: tank epiphyte; when flowering 16in.; leaves yellow/green, to 18 in., white, chalky, powder covering, especially at the base; flowers 15-50, 3/8 $1 / 2$ in., white, on a stout scape, usually with 2-8 lateral branches; floral bracts $1 / 4-1 / 3$ in., sepals $1 / 2$ in. yellow-green; seed capsule $\sim 1 / 2$ in. long; seeds often germinate on the capsule

Time of flowering: all year, especially fall-winter

Fun facts: one of three known carnivorous bromeliads; slippery powder on leaf bases may aid in trapping insects

\section{Florida strap airplant}

\section{Scientific name: Catopsis floribunda}

Also called: Many-flowered catopsis, Many-flowered airplant, Florida catopsis

$\underline{\text { Status in Florida: endangered, rare }}$

Threats in Florida: illegal collecting, habitat loss, Mexican bromeliad weevil

Range: Florida, Mexico, West Indies, Central and South America

Distribution in Florida: Broward, Collier, Dade, and Monroe counties

Habitat: humid, shady habitats; rockland hammocks; cypress swamps

Description: tank epiphyte; grows to 28 in. tall; leaves bright green, 8in., with wide bases and narrowing at tip; flower stalk 10 in. or longer, with 5-15 lateral branches; flowers 15-50 yellow or white; seed capsules $1 / 2$ in. long; vegetative in every month

Time of flowering: fall 


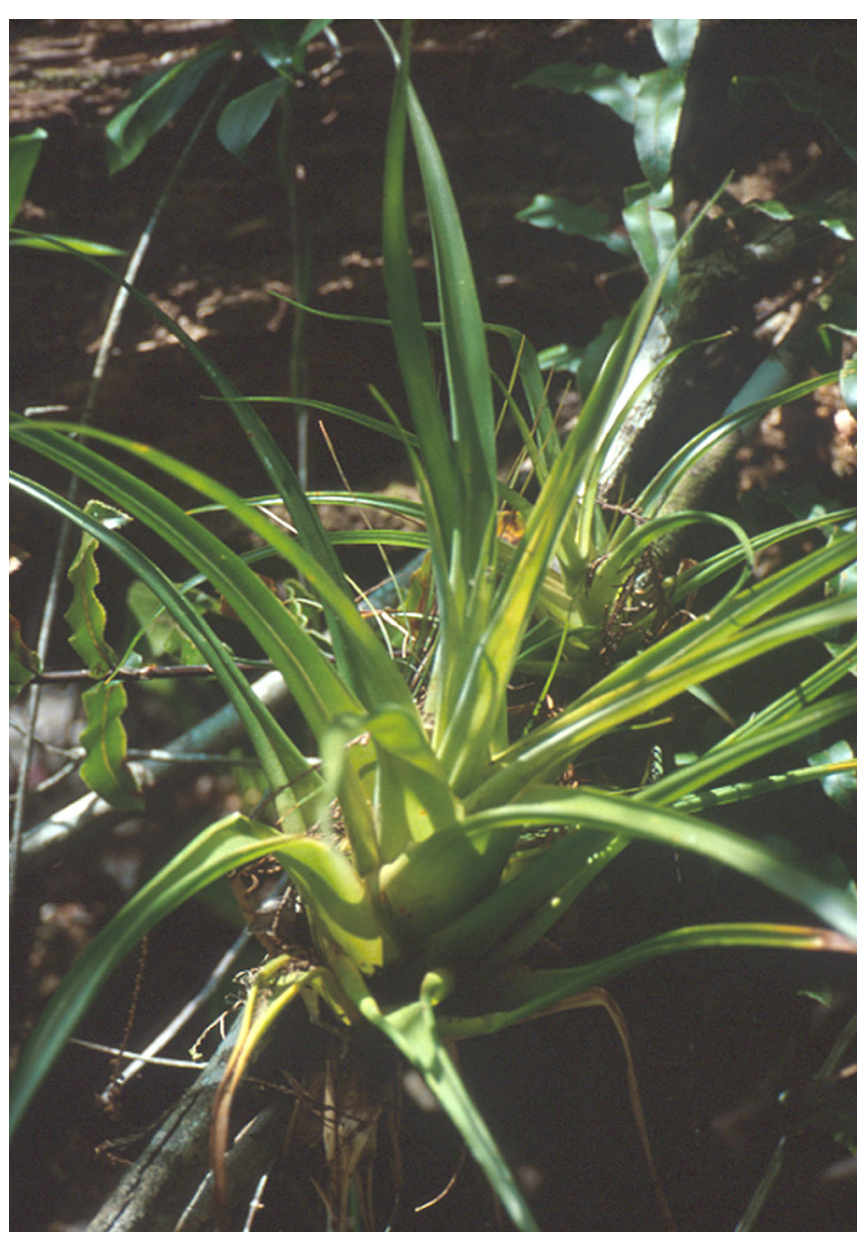

Florida strap airplant. Credits: J. H. Frank

Fun facts: soft leaves form a basal rosette; prefers shady spots on low tree branches.

\section{Nodding strap airplant}

Scientific name: Catopsis nutans

Also called: Nodding airplant, Nodding catopsis

Status in Florida: endangered, very rare

Threats in Florida: restricted range, illegal collecting, Mexican bromeliad weevil

Range: Florida, Mexico, West Indies, Central and South America

\section{Distribution in Florida: Collier County}

Habitat: shady, humid hammocks, deep cypress swamp, sloughs

Description: tank epiphyte; height 12 in; leaves small rosettes overlapping at bases, flexible, spreading,

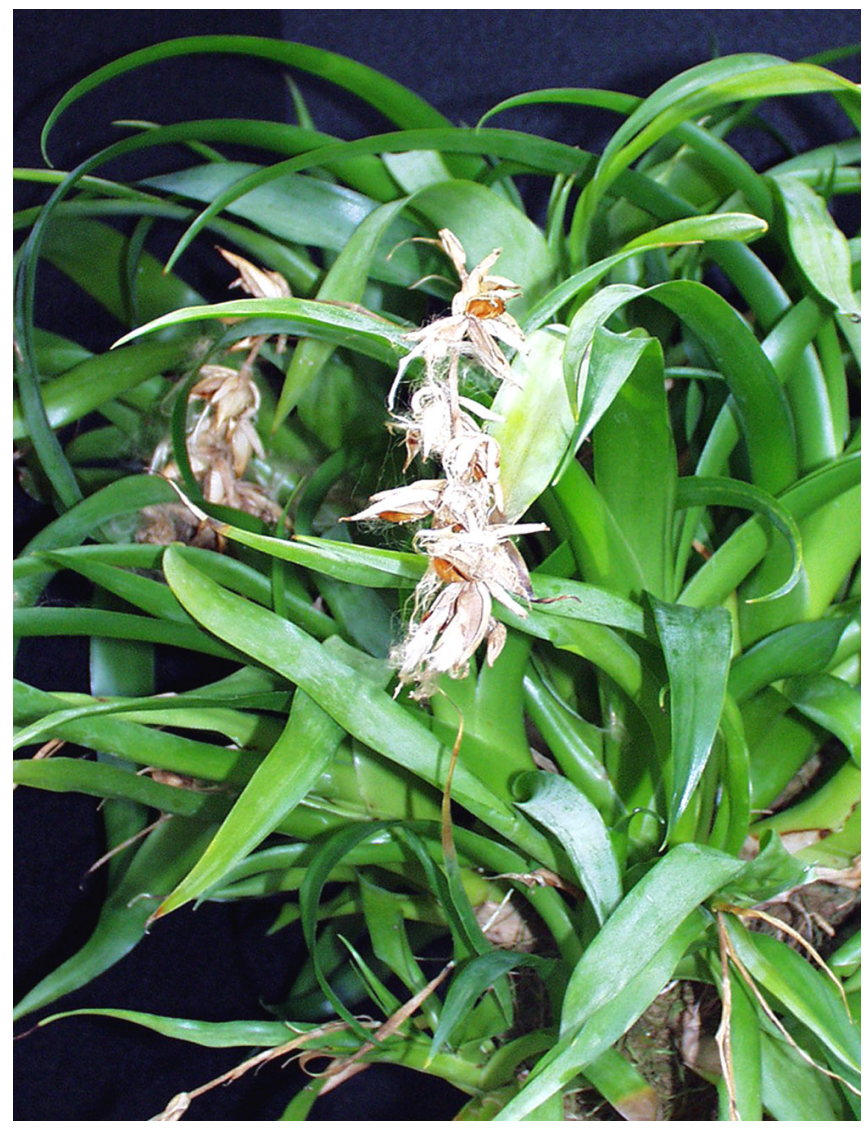

Nodding strap airplant. Credits: B. Holst

bright green, tapered to tip, 3-6 in. long, 3/4 in. wide at base, chalky; flower stalk usually simple; flowers 3-10 orange/yellow, $3 / 4$ in.; capsules 1/2 - 3/4 in. long, oval

Time of flowering: fall-spring (August-October)

Fun facts: flowers open at night; may only exist in the Fakahatchee Strand

\section{West Indian tufted airplant}

Scientific name: Guzmania monostachia

Also called: Fuchs bromeliad, Strap-leaved Guzmania, Striped torch

Status in Florida: endangered, restricted, seldom found but locally abundant

Threats in Florida: illegal collecting, Mexican bromeliad weevil

Range: Florida, West Indies, Mexico, Central America to northern Peru and Brazil 


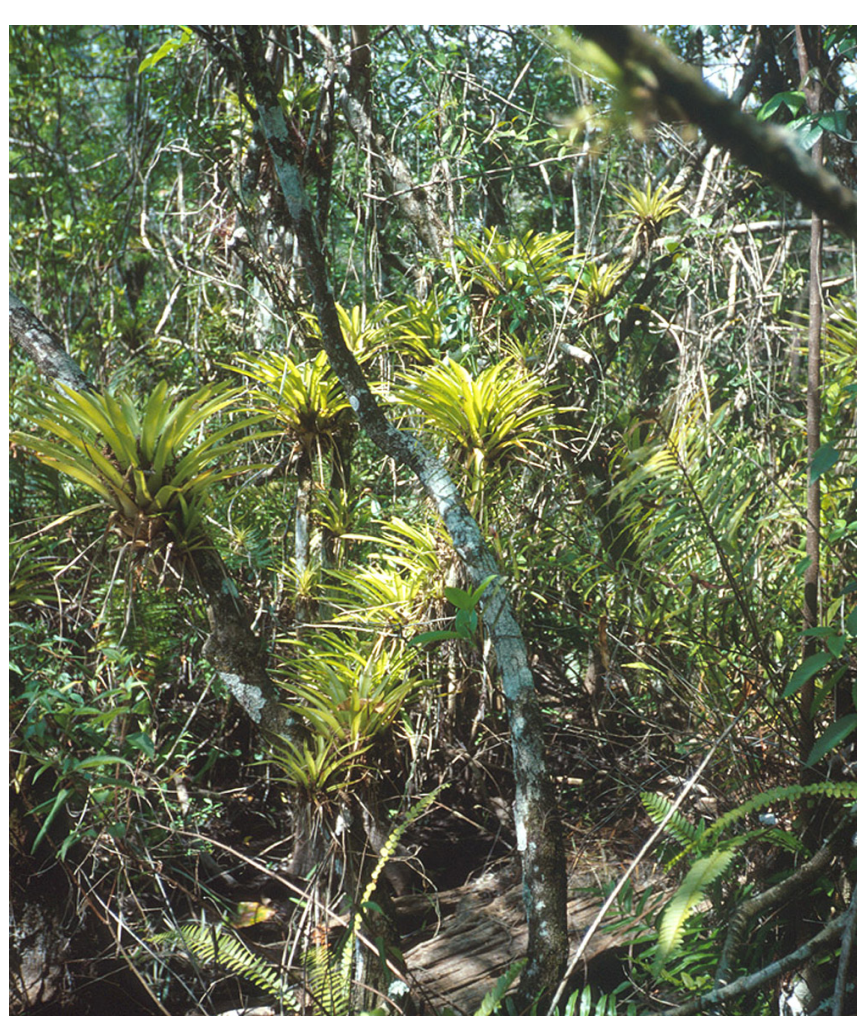

West Indian tufted airplant. Credits: J. H. Frank

Distribution in Florida: Collier, Dade, mainland Monroe counties

Habitat: rockland hammock, slough, cypress swamp, most abundant on Pop ash (Fraxinus caroliniana) and Pond apple (Annona glabra) sloughs with peat soils

Description: Tank epiphyte; may be terrestrial; bright green, flexible, non leaves taper at the tip, about $1 \mathrm{in}$. wide, usually 10-12 in., may have white stripes; single floral spike to 16 in.; many white flowers spirally arranged, 1 in.; salmon colored apical floral bracts; cylindrical seed capsules, 1 1/2 in.

Time of flowering: all year, mainly February-August and especially May-July

Fun facts: 100 plants may appear on a single host tree; may produce many vegetative offshoots; genus name honors the 18th Century Spanish naturalist Guzman

\section{Leatherleaf airplant}

Scientific name: Tillandsia variabilis syn $T$. valenzuelana

Also called: Soft-leaved wild pine

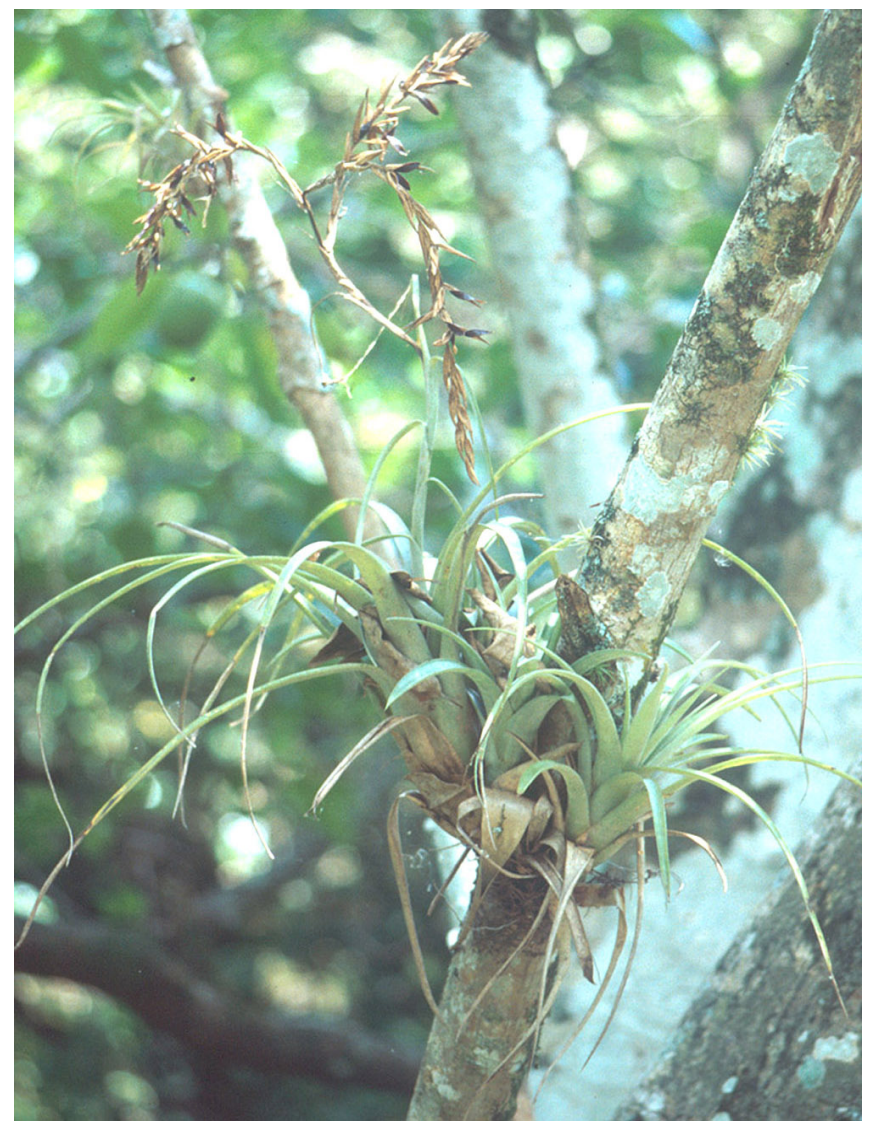

Leatherleaf airplant. Credits: Barbra Larson

$\underline{\text { Status in Florida: threatened, occasional }}$

Threats in Florida: illegal collecting, Mexican bromeliad weevil, habitat loss

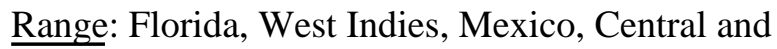
South America

Distribution in Florida: Broward, Collier, Hendry, Highlands, Martin, Dade, Monroe, Okeechobee counties

Habitat: shaded hammocks, cypress swamps

Description: tank epiphyte; plants usually single; 12-20 in tall; 15-20 soft leaves with fine scales, green/gray or silver (may have rose coloring), tapering; simple flower spike with reddish floral bracts $13 / 8$ in. long), violet petals, and white sepals

Time of flowering: spring-fall

Fun facts: color of the flower spike depends greatly on the light level; summer colors are darker than fall 


\section{Giant airplant}

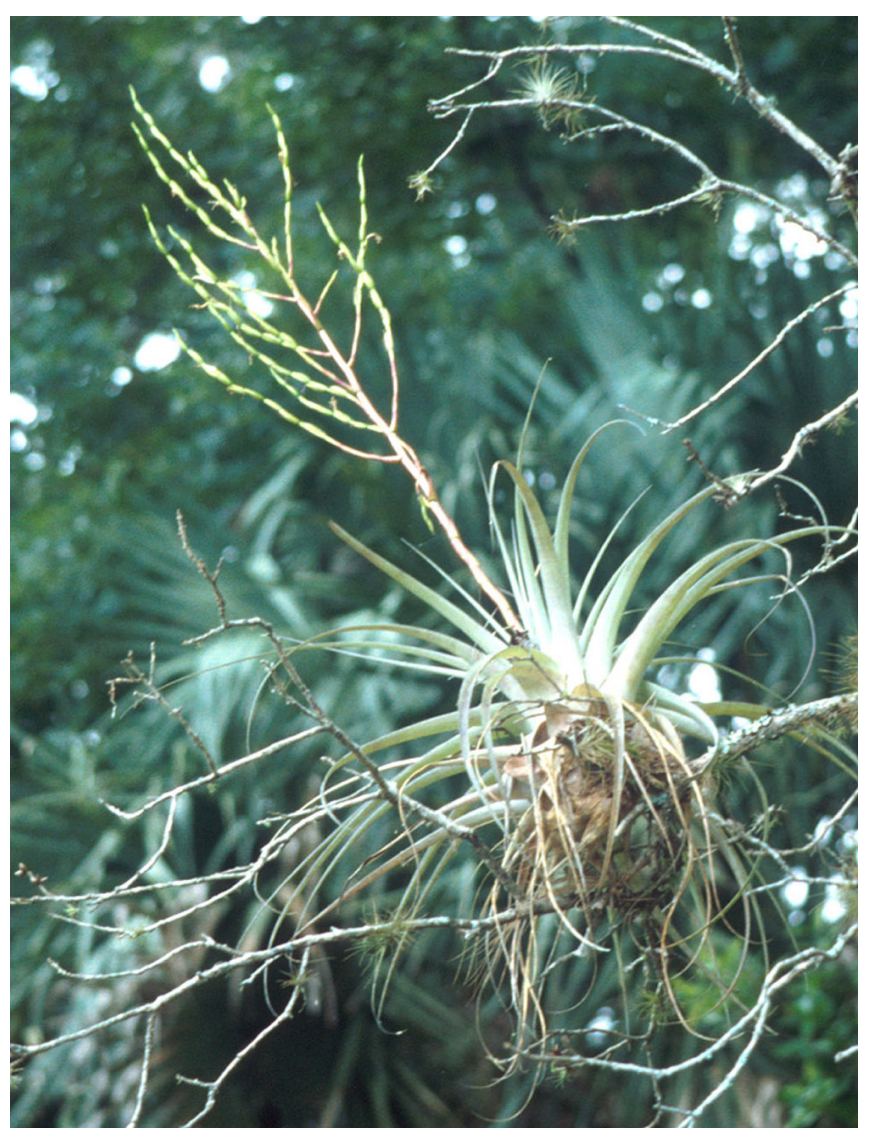

Giant airplant. Credits: Barbra Larson

\section{Scientific name: Tillandsia utriculata}

Also called: Giant/Swollen wild pine; Spreading air plant

Status in Florida: endangered, frequent before Mexican bromeliad weevil

Threats in Florida: illegal collecting, Mexican bromeliad weevil, habitat loss

Range: Florida, West Indies, Mexico, Central/South America

Distribution in Florida: Putnam, Flagler, Sumter, Lake, and Citrus counties, south to end of peninsula

Habitat: dry and mesic hammocks, cypress swamps, pinelands (often in bright exposed areas)

Description: tank epiphyte (may grow terrestrial); single plants, 6-12 ft.; 20-75 large, light- to grayleaves (up to 31 in.) with wide base and scales; erect, zigzag branching flower spike (40-80 in.) 5-40 branches; floral bracts green or purple; 10-200 flowers, 1 in. petals white at base, violet at end; seed capsules up to 2 in.; monocarpic (single flower spike, releases seed and dies); low rate of vegetative reproduction

Time of flowering: spring to fall (especially summer)

Fun facts: after flower spike appears, seeds are released the following year in late spring; plant may live 20 years

\section{Northern needleleaf}

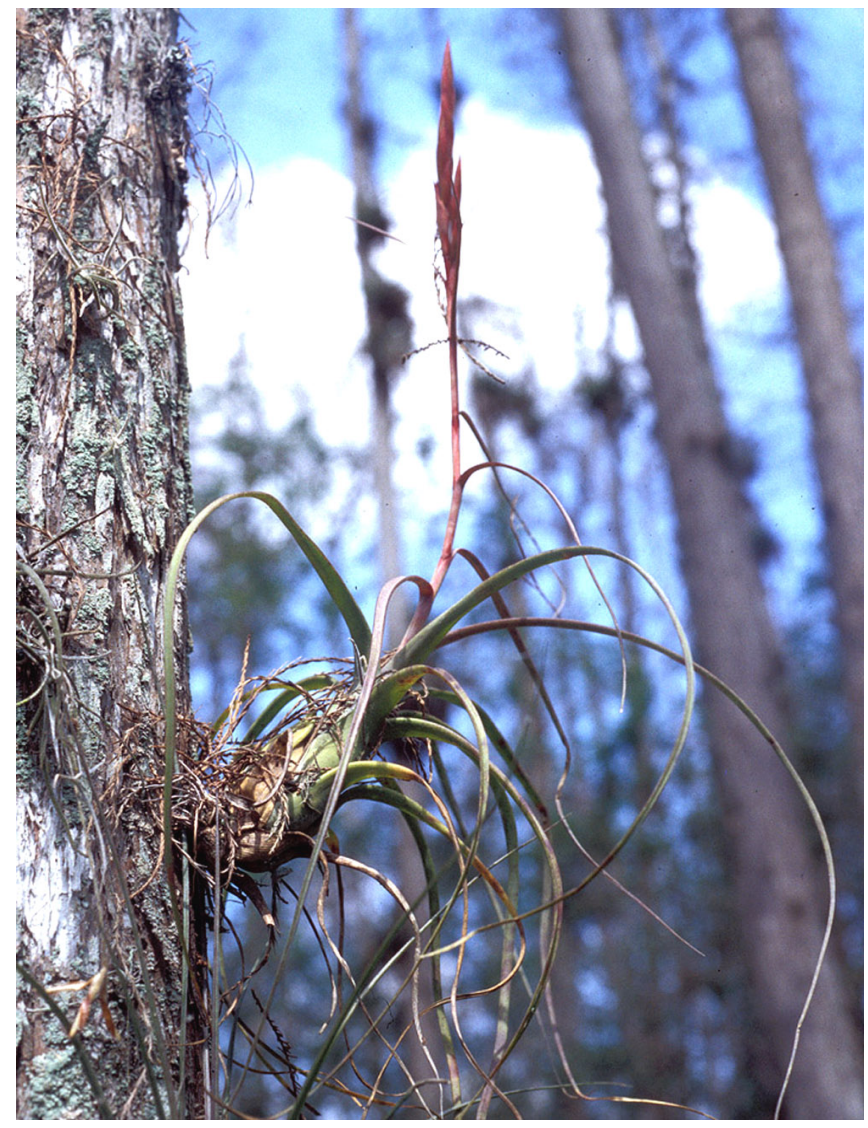

Northern needleleaf. Credits: Barbra Larson

Scientific name: Tillandsia balbisiana

Also called: Inflated wild pine, Reflexed wild pine, Cuttlefish, Balbis airplant

Status in Florida: threatened, occasionally found

Threats in Florida: Mexican bromeliad weevil, habitat loss 
Range: Florida, Mexico, West Indies, Central and South America

Distribution in Florida: Orange, Osceola, Polk, Hillsborough, Manatee, Sarasota, DeSoto, Highlands, Okeechobee, Indian River, St. Lucie, Martin, Glades, Charlotte, Lee, Hendry, Palm Beach, Broward, Collier, Monroe, and Dade counties

Habitat: scrub, pinelands, cypress swamp, hammocks, mangroves, shell ridges/mounds

Description: Tank epiphyte; 28 in. tall, single or in clusters; 15-30 leaves, leathery, gray color due to scales, may be reddish; leaves slightly bulbous at base, tapering, curved or twisted at ends; flower spike usually 2-10 lateral branches, scape 3-12 in.; floral bracts bright red with violet petals, 5flowers; seed capsules $13 / 4$ in.

Time of flowering: fall-summer, especially early spring

Fun facts: on older plants, twisted and curved leaves interlock, forming a ball

\section{Bartram's airplant}

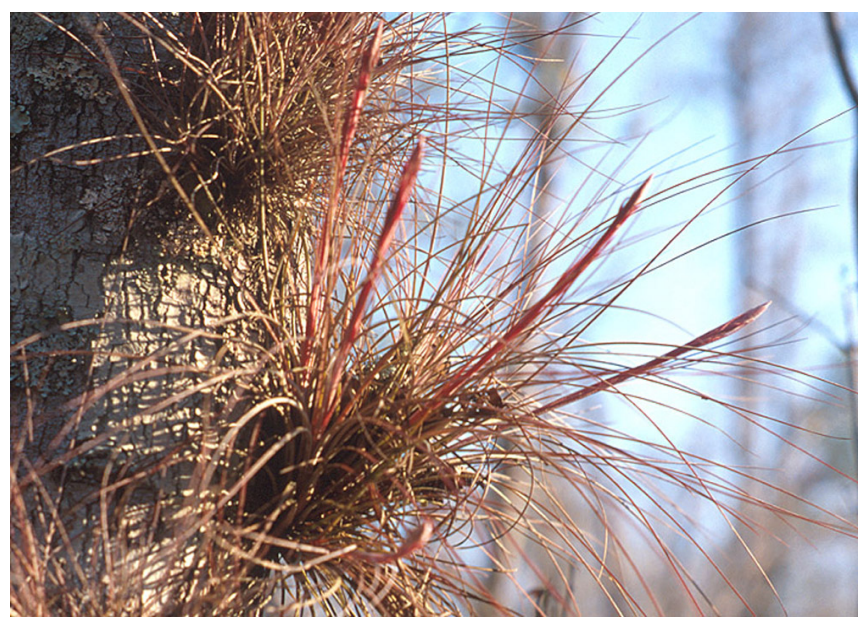

Bartram's airplant. Credits: J. H. Frank

Scientific name: Tillandsia bartramii,

syn $T$. juncea, T. myriophylla

Status in Florida: frequently found

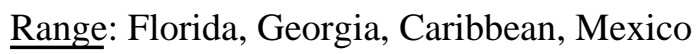

Distribution in Florida: Alachua, Baker, Bradford, Citrus, Columbia, Dixie, Duval, Flagler, Franklin, Gilchrist, Gulf, Hernando, Highlands, Hillsborough, Indian River, Jefferson, Lafayette, Lake, Leon, Levy, Liberty, Manatee, Marion, Nassau, Orange, Osceola, Pasco, Polk, Putnam, Seminole, St. Johns, Sumter, Suwannee, Volusia, and Wakulla counties

Habitat: hammocks and pinelands

Description: epiphytic; 4-12 in. tall, 18-16 in. when flowering; plants clustered; 15thin leathery, grayish leaves; flower spike simple or 1-5 side branches; pink to red floral bracts; 5 flowers; seed capsules $\sim 1$ inch

Time of flowering: spring-summer (especially spring)

Fun facts: leaves resemble those of a wetland rush; Bartram was an early Florida naturalist

\section{Cardinal airplant}

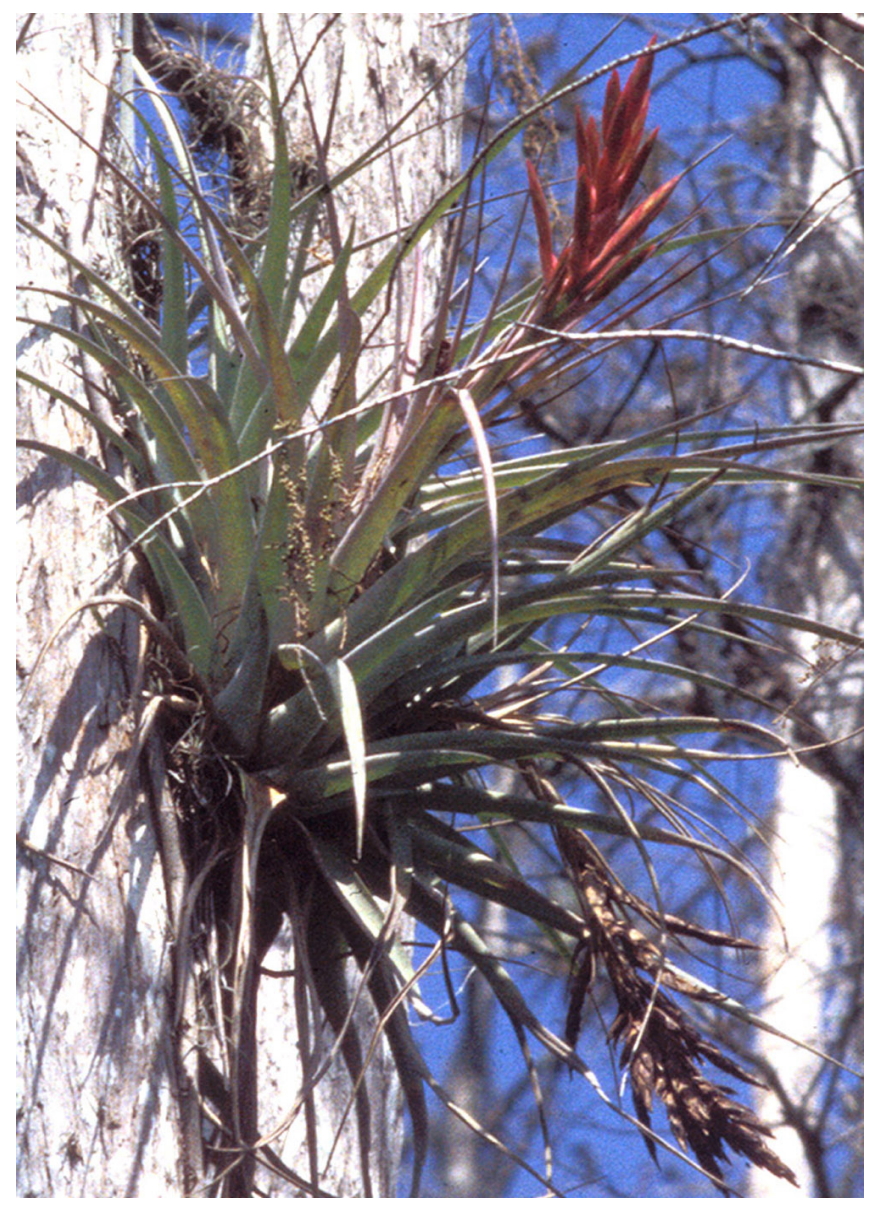

Cardinal airplant. Credits: Barbra Larson 


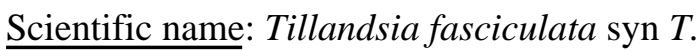
hystricina

Also called: Quillairplant, Common wild pine, Clustered wild pine, Dog

Status in Florida: endangered; frequent before weevil

Threats in Florida: illegal collecting, Mexican bromeliad weevil, habitat loss

$\underline{\text { Range: }}$ Florida, West Indies, Mexico, Central and South America

Distribution in Florida: Brevard, Broward, Charlotte, Collier, DeSoto, Glades, Hardee, Hendry, Highlands, Hillsborough, Lee, Manatee, Martin, Dade, Monroe, Okeechobee, Orange, Osceola, Palm Beach, Pinellas, Polk, Sarasota, Seminole, and Volusia counties

Habitat: hammocks, cypress swamps, pinelands

Description: tank epiphyte, often in clusters; 20-50 long, stiff and leathery gray/green leaves, (12-28 in.), wider at brown base, tapering; flowering spike 12-24 in., 3-15 branches; floral bracts usually red but vary from yellow, green, to rose; $10-50$ violet flowers, violet, rarely white, $13 / 4$ in.; seed capsules $\sim 1$ in.; seeds windborne

Time of flowering: all year, especially spring to early summer

Fun facts: leaves longer in shade, plant smaller and more colorful in open sun

\section{Twisted airplant}

Scientific name: Tillandsia flexuosa syn T. aloifolia

Also called: Banded/Striped airplant; Flexuous wild pine Status in Florida: threatened, infrequent

Threats in Florida: illegal collecting, Mexican bromeliad weevil, habitat loss

Range: Florida, West Indies, Panama, Venezuela, Colombia

Distribution in Florida: Broward, Charlotte, Collier, Hendry, Highlands, Lee, Martin, Dade, Monroe, Palm Beach counties

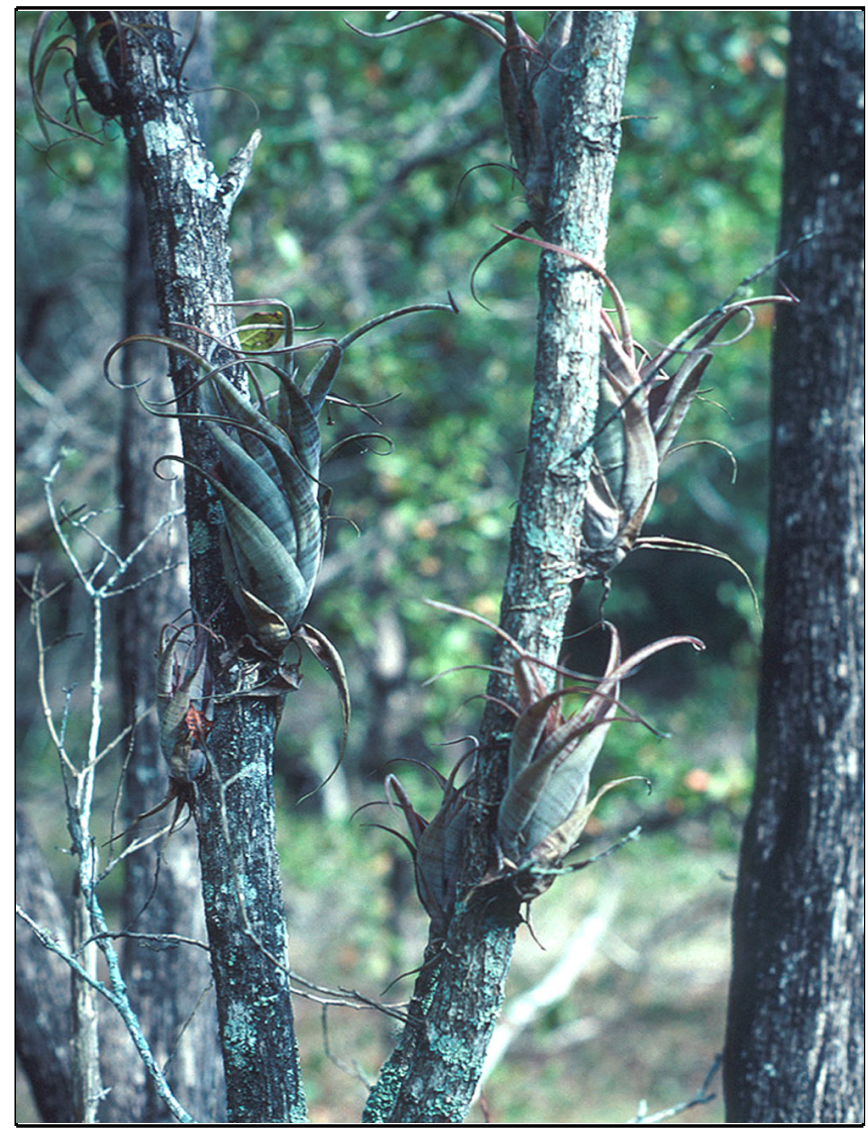

Twisted airplant. Credits: J. H. Frank

Habitat: exposed areas, often coastal; xeric hammock, pinelands, scrub, shell mound, coastal berm, maritime hammock, tidal swamp, cypress swamp

Description: tank epiphyte; 8-31 in., bulbous base, gray leaves, twisted tips, white bands; zigzag flower stalk simple or few branches; spreading floral bracts; rose or purple flowers, 1 1/2 in.; capsules 2 in.

Time of flowering: all year, except November and December, mostly spring to summer

Fun facts: flowers once, then reproduces vegetatively

\section{Potbelly airplant}

Scientific name: Tillandsia paucifolia syn $T$. circinnata, T. bulbosa

Status in Florida: occasional

Threats in Florida: Mexican bromeliad weevil

Range: Florida, Mexico, West Indies, Central and South America 


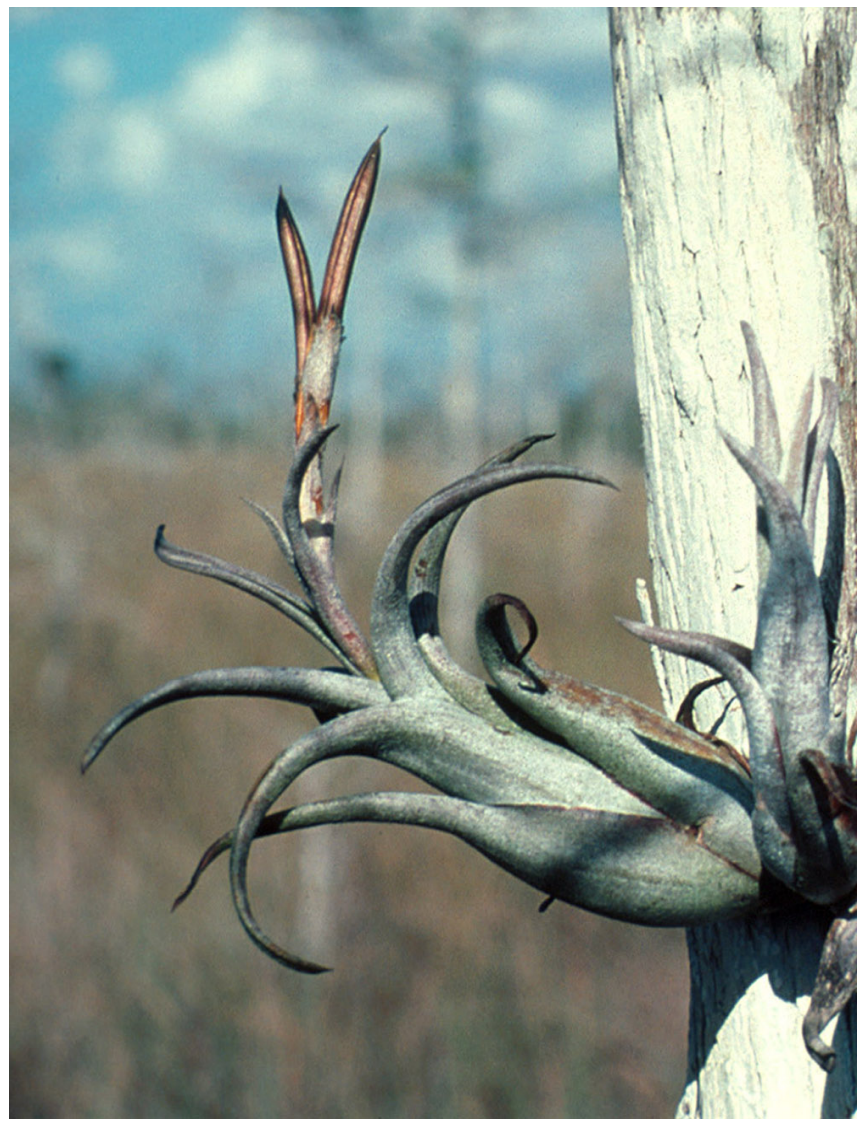

Potbelly airplant. Credits: J. H. Frank

Distribution in Florida: Brevard, Broward, Charlotte, Collier, Hendry, Indian River, Lee, Manatee, Martin, Dade, Monroe, Okeechobee, Osceola, Palm Beach, Sarasota, and St. Lucie counties

Habitat: coastal strands and hammocks; exposed habitats, cypress swamps

Description: Tank epiphyte; 4-14 in. tall, single or in clusters; pseudobulbs; 5-10 long, twisted tapering gray leaves; simple flower spike 2-3 in., may have 2-4 branches, 2-15 lavender flowers $\sim 1$ in; leathery, pale pink floral bracts; brown, pointed seed capsules 1 1/2 in.

\section{Time of flowering: spring summer}

Fun facts: only flowers once, then produces young sprout "pups" that feed off the mother plant until they drop off

\section{Fuzzywuzzy airplant}

Scientific name: Tillandsia pruinosa syn $T$. breviscapa

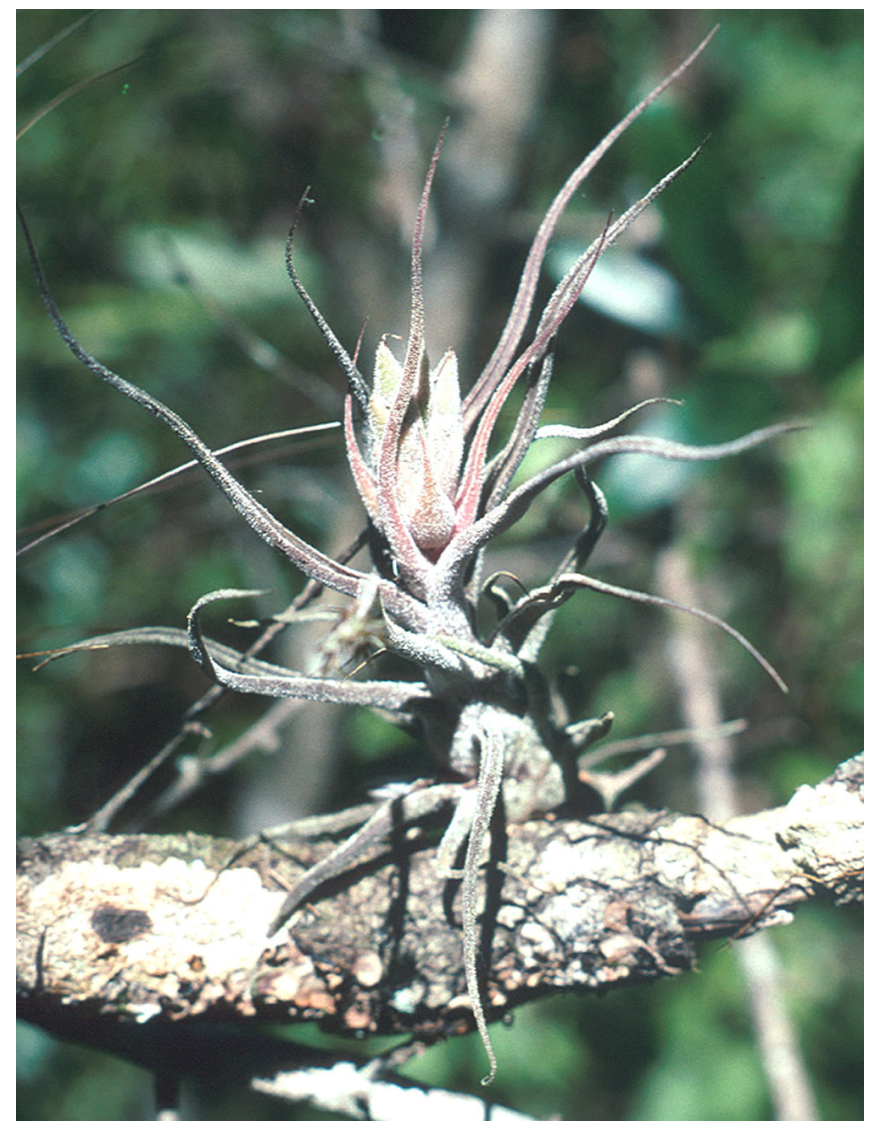

Fuzzywuzzy airplant. Credits: J. H. Frank

Also called: Hoary airplant, Tropical airplant

Status in Florida: endangered, rare

Threats in Florida: illegal collecting, Mexican bromeliad weevil, habitat loss

Range: Florida, West Indies, Central and South America

\section{Distribution in Florida: Collier County}

Habitat: shady, humid hammocks, cypresss swamps

Description: Tank epiphyte, pseudobulb, rarely clustered; 10 in. tall, 5-10 leaves; scales create white fuzzy appearance; flower spike simple; floral bracts pink, with 5 to many violet flowers, $\sim 1$ in.; seed capsule pointed and 3-sided, $13 / 4$ in.

Time of flowering: All year, especially winter to spring

Fun facts: pointed scales give this plant its fuzziness; short flower stalks are sometimes hidden 


\section{Ball moss}

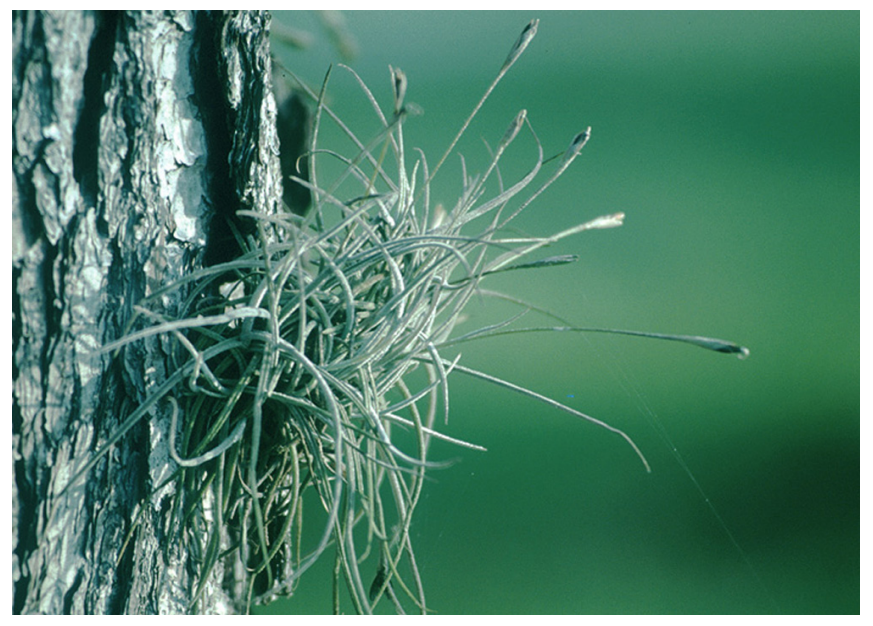

Ball moss. Credits: Barbra Larson

Scientific name: Tillandsia recurvata syn

Diaphoranthema recurvata

Status in Florida: common

Threats in Florida: none

Range: Arizona, Texas, Louisiana, Georgia, Florida, Mexico, Central America, West Indies, Argentina, Chile

Distribution in Florida: all counties

Habitat: Hammocks (prefer broad-leaved trees), pinelands, scrub; exposed areas

Description: Epiphytic; 5-7 in. tall, 6-7 in. wide; rooted crown, cluster of curving stems, compact leaves resulting in ball-like growth; leaves stiff, narrow, gray 2-5 blue to violet flowers on long central stem; seed capsule $\sim 1$ in. long

Time of flowering: spring

Fun fact: several plants often grow together in masses

\section{Southern needleleaf}

Scientific name: Tillandsia setacea Syn T. tenuifolia

Also called: Needleleaf airplant

Status in Florida: common

Threats in Florida: none

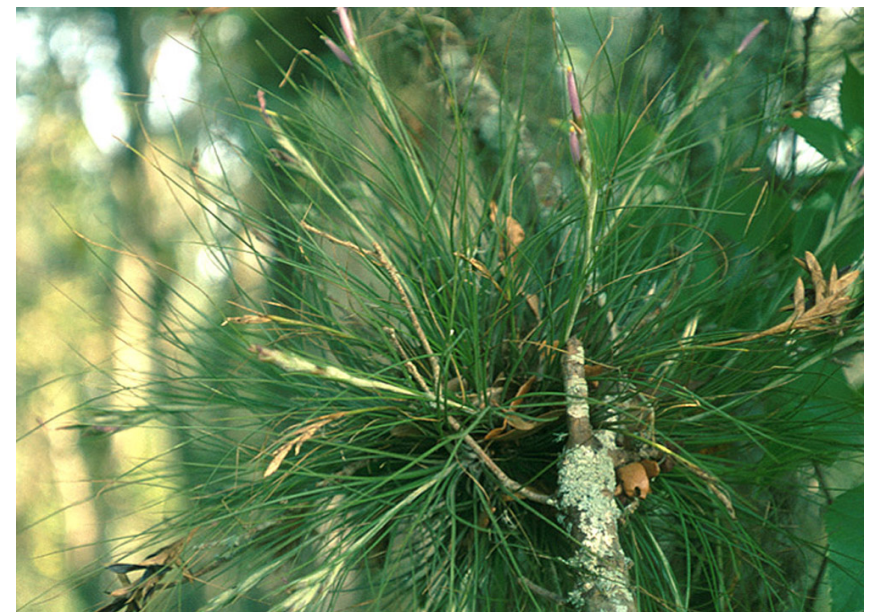

Southern needleleaf. Credits: J. H. Frank

Range: Florida, West Indies, Central and South America

Distribution in Florida: Brevard, Broward, Charlotte, Collier, DeSoto, Glades, Hardee, Hendry, Hernando, Highlands, Hillsborough, Indian River, Lake, Lee, Manatee, Martin, Dade, Monroe, Okeechobee, Orange, Osceola, Palm Beach, Pasco, Pinellas, Polk, Putnam, Sarasota, Seminole, St. Lucie, Sumter, and Volusia counties

Habitat: hammocks, swamps

Description: epiphytic, grows to 12 in. long, plants densely clustered, grow in small tufts; leaves swollen at base, curving tips, green to red; flower stalk 3-6 in.; 3-15 violet flowers, 1 in. long; seed capsules $~ 1$ in.

Time of flowering: spring

Fun fact: similar to Tillandsia bartramii except for red tinting

\section{Broad needleleaf}

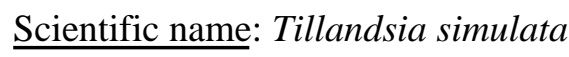

Status in Florida: frequent; found nowhere else

Threats in Florida: possibly Mexican bromeliad weevil

Range: Florida

Distribution in Florida: Citrus, DeSoto, Flagler, Hernando, Highlands, Hillsborough, Indian River, 


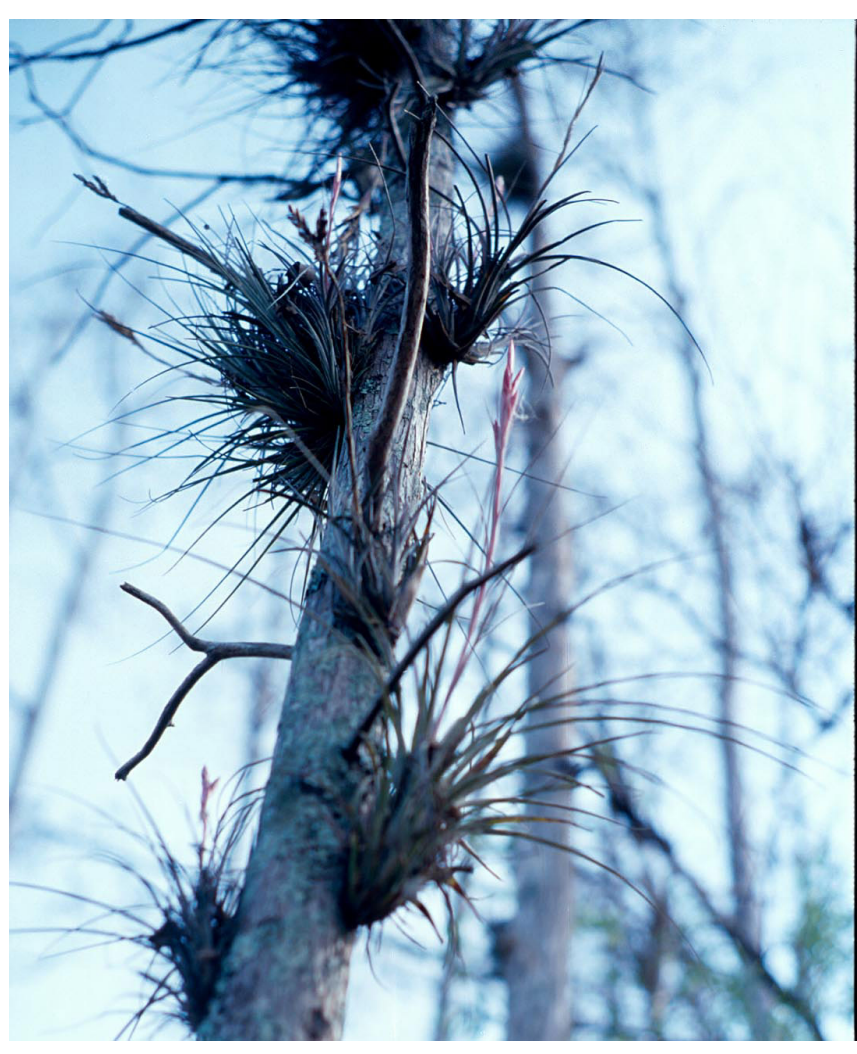

Broad needleleaf. Credits: J. H. Frank

Lake, Levy, Manatee, Orange, Osceola, Pasco, Pinellas, Polk, Putnam, Seminole,

Sumter, and Volusia counties

Habitat: moist hammocks, swamps, usually in strong light

Description: epiphytic, single or in clusters; 8-16 in. tall; gray pointed leathery leaves; simple flower spike with reddish floral bracts; 5-30 violet flowers, 1 3/4 in. long; seed capsules $\sim 1$ in.

Time of flowering: spring-summer

Fun facts: the only bromeliad species known only from Florida

\section{Spanish moss}

\section{Scientific name: Tillandsia usneoides syn}

Dendropogon usneoides

Status in Florida: common

Threats in Florida: none

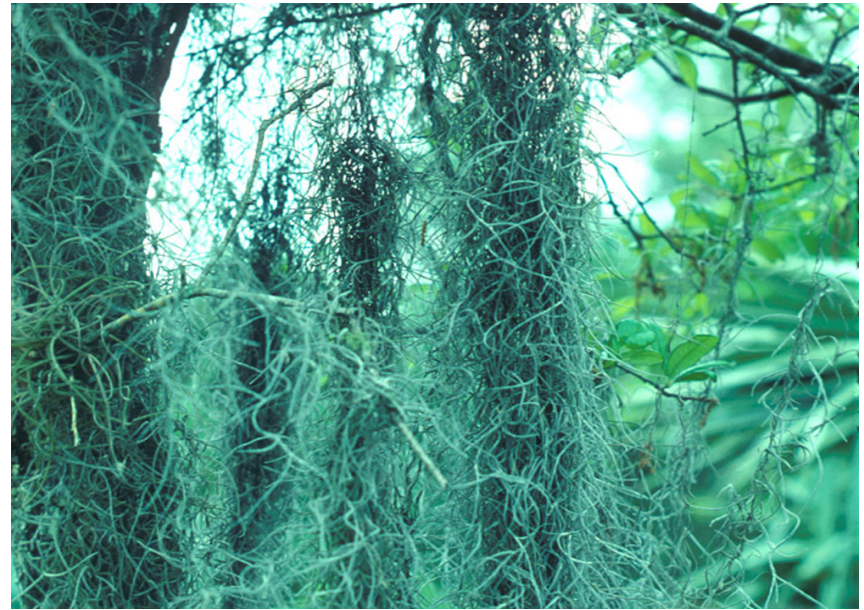

Spanish moss. Credits: J. H. Frank

Range: Virginia, North Carolina, South Carolina, Georgia, Florida, Alabama, Louisiana, Mississippi, Arkansas, Texas to central Argentina and Chile

Distribution in Florida: all counties

Habitat: hammocks (usually on oaks), pinelands and scrub; prefers moist, brightly exposed areas

Description: epiphytic; rootless, 1ong branching, up to 18 in. long; leaves 1-2 in. long, 1/16 in. wide, covered with grayscales; leaves greener when plant healthy; flowers, usually one, greenishfragrant, lasting 4 days; seed capsules 1/2-3/4 in. long: seeds 2-23 per capsule, reproduces by seed and vegetatively

$\underline{\text { Time of flowering: spring (mainly April) }}$

Fun facts: "ginned" in Florida in early 1900s; bales exported for car seats and mattresses; broadest geographical range of any bromeliad; gray leaves may indicate moisture stress or other environmental factors; can withstand extreme temperature fluctuation and low rainfall

\section{References and Additional Information}

Arny, Nancy P. 1996. Spanish Moss and Ball Moss. UF/IFAS FOR 52. School of Forest Resources and Conservation, http://edis.ifas.ufl.edu.

Bennett, Bradley C. 1992. The Florida bromeliads, Guzmania monostachia. Journal of the Bromeliad Society 42(6): 266 
Coile, Nancy C. 2000. Notes on Floridas

Endangered and Threatened Plants. FDACS/DPI, Bureau of Entomology, Nematology and Plant Pathology, Botany Section. Contribution No. 38, 3rd ed., Gainesville, FL.

(http://www.virtualherbarium.org/EPAC).

Flora of North America Association. 2000. Flora of North America, Vol. 22.

http://flora.huh.harvard.edu/FNA.

Florida Department of Agriculture and Consumer Services, Division of Plant Industry, Regulated Plant Index, (

http://doacs.state.fl.us/pi/enpp/botany/images/ Notes2003.pdf).

Florida Natural Areas Inventory. 1997. Matrix of Habitats and Distribution by County of Rare/Endangered species of Florida. Florida Natural Areas Inventory/The Nature Conservancy. (http://www.fnai.org).

Frank, J.H. 1996. Carnivorous bromeliads. (http://BromeliadBiota.ifas.ufl.edu/carnbr.htm).

Frank, J.H. 1996. Bromeliad phytotelmata. (http://BromeliadBiota.ifas.ufl.edu/bromfit.htm).

Frank, J.H. 1996. Pests of bromeliads. (http://BromeliadBiota.ifas.ufl.edu/bropes.htm)

Hall, David W. 1993. Illustrated Plants of Florida and the Coastal Plain. Maupin House, Gainesville, FL.

Langdon, K.R. 1980. The bromeliad, Guzmania monostachya, An Endangered Plant in Florida. Nematology Circular No. 69 (Botany 12). Contribution NO. 220, Bureau of Nematology. FDACS/DPI, Gainesville, FL.

Larson, Barbra and J. Howard Frank. 2000. Mexican Bromeliad Weevil, Metamasius callizona (Chevrolat). UF/IFAS Featured Creatures. EENY-161. (http://creatures.ifas.ufl.edu/orn/m_callizona.htm).

Larson, Barbra, J. Howard Frank, and Olan Ray Creel. 2001. Florida Bromeliad Weevil, Metamasius mosieri Barber. UF/IFAS Featured Creatures.

EENY-209.

(http://creatures.ifas.ufl.edu/orn/m_mosieri.htm).

Long, Robert W. and Olga Lakela. 1976. A Flora of Tropical Florida. Banyan Books, Miami.

Save Florida's Native Bromeliads, A Project of the Florida Council of Bromeliad Societies and the University of Florida/IFAS.

(http://savebromeliads.ifas.ufl.edu).

Sutton, David L. 1999. Aquatic, Wetland and Invasive Plant Glossary, University of Florida, Institute of Food and Agricultural Sciences, (http://aquat1.ifas.ufl.edu/glossary.html).

Ward, Daniel B. (ed.). 1979. Plants Vol. 5, In: Rare and Endangered Biota of Florida, P.C.H. Pritchard (ed.). University Presses of Florida, Gainesville, 175 pp. 